This Accepted Author Manuscript is copyrighted and published by Elsevier. It is posted here by agreement between Elsevier and University of Brasilia. Changes resulting from the publishing process - such as editing, corrections, structural formatting, and other quality control mechanisms - may not be reflected in this version of the text. The definitive version of the text was subsequently published in [Journal of Invertebrate Pathology, Volume 72, Issue 3, November 1998, Pages 239-245, doi:10.1006/jipa.1998.4788].You may download, copy and otherwise use the AAM for non-commercial purposes provided that your license is limited by the following restrictions:

(1) You may use this AAM for non-commercial purposes only under the terms of the CC-BY-NCND license.

(2) The integrity of the work and identification of the author, copyright owner, and publisher must be preserved in any copy.

(3) You must attribute this AAM in the following format: [agreed attribution language, including link to CC BY-NC-ND license + Digital Object Identifier link to the published journal article on Elsevier's ScienceDirect ${ }^{\circledR}$ platform].

Este Manuscrito do Autor Aceito para Publicação (AAM) é protegido por direitos autorais e publicado pela Elsevier. Ele esta disponível neste Repositório, por acordo entre a Elsevier e a Universidade de Brasília. As alterações decorrentes do processo de publicação - como a edição, correção, formatação estrutural, e outros mecanismos de controle de qualidade - não estão refletidas nesta versão do texto. A versão definitiva do texto foi posteriormente publicado em [Journal of Invertebrate Pathology, Volume 72, Número 3, Novembro de 1998, Páginas 239-245 doi:10.1006/jipa.1998.4788]. Você pode baixar, copiar e utilizar de outra forma o AAM para fins não comerciais, desde que sua licença seja limitada pelas seguintes restrições:

(1) Você pode usar este AAM para fins não comerciais apenas sob os termos da licença CC- BYNC-ND.

(2) A integridade do trabalho e identificação do autor, detentor dos direitos autorais e editor deve ser preservado em qualquer cópia.

(3) Tem de atribuir este AAM no seguinte formato: [acordo na linguagem atribuída, incluindo o link para CC BY-NC-ND licença Digital + DOI do artigo publicado na revista Elsevier ScienceDirect ${ }^{\circledR}$ da plataforma]. 


\title{
Structural and Ultrastructural Changes during the Infection of UFL-AG- 286 Cells with the Baculovirus AgMNPV
}

\author{
Vivian Pombo \\ Lucas Malard Velloso \\ Bergmann M. Ribeiro \\ Sonia N. Báo
}

\begin{abstract}
During infection of the permissive insect cell line UFL-AG-286 by the baculovirus Anticarsia gemmatalis nucleopolyhedrovirus (AgMNPV-2D) several morphological changes occur. By $12 \mathrm{~h}$ postinfection (h p.i.), the infected cells became round and exhibited a decrease in the number of cytoplasmic projections. By $24 \mathrm{~h}$ p.i., it was possible to detect a virogenic stroma inside the cell nucleus, and after $48 \mathrm{~h}$ p.i., polyhedral inclusion bodies were observed. Some of these morphological modifications are probably due to changes in the cytoskeleton of the cell and this possibility was substantiated by the observation that the distribution of actin and microtubules was dramatically modified upon infection. Several viral-induced proteins were also produced during infection and a sharp decrease in overall protein synthesis was observed. These results are very similar to those obtained with other cell lines infected with different baculoviruses, indicating a similar mechanism of infection.
\end{abstract}

Keywords: AgMNPV; baculovirus; cytoskeleton; insect cell; structure; ultrastructure.

\section{INTRODUCTION}

In addition to being a potential source of biopesticides for the control of insect pests, baculoviruses are being used as vectors for the expression of hundreds of different genes (O'Reilly et al., 1992). Baculoviruses belong to the Baculoviridae family of insect viruses, with rod-shaped virions containing double-stranded circular DNA of more than 100,000 bp. The Baculoviridae family is subdivided into Nucleopolyhedroviruses and Granuloviruses (Murphy et al., 1995). A characteristic of the baculoviruses is the presence of two forms of the virus during infection, the occluded and budded virus forms. The occluded form of the virus is produced in the last phase of the infection and comprises nucleocapsids embedded in a protein matrix forming an occlusion body that protects the virus in the environment (for a review see Volkman and Keddie, 1990). The Nucleopolyhedroviruses have occlusion bodies (polyhedra) from 1 to $15 \mu \mathrm{m}$ in size with a matrix composed mainly of a protein (polyhedrin) of around 30 kDa (Maruniak, 1986). Polyhedra are responsible for horizontal transmission of the infection from insect to insect. The budded virus form comprises single nucleocapsids with a lipid envelope, is produced before the occluded form, and is responsible for the systemic spread of the infection within the insect (Volkman and Keddie, 1990). 
With the development of insect cell cultures, it became possible to follow the structural and ultrastructural changes of insect cells infected with different baculoviruses. Changes of cytoskeleton components of a cell line derived from Spodoptera frugiperda (IPLBSF-21) (Vaugh et al., 1977) by the baculovirus prototype Autographa californica nucleopolyhedrovirus (AcMNPV) showed that the cytoskeleton of the cell was dramatically reorganized during infection (Volkman et al., 1987, 1996; Volkman and Zaal, 1989; Hess et al., 1989; Charlton and Volkman, 1991, 1993; Lanier et al., 1996). These changes in the cytoskeleton of the cells probably lead to some of the cytopathological effects observed during infection, such as rounding of the cell (Volkman and Keddie, 1990) and nuclear hypertrophy (Witt et al., 1977). They may also be involved in the synthesis, transport, and assembly of virus particles inside the cell (Volkman et al., 1987; Hess et al., 1989; Charlton and Volkman, 1991).

Anticarsia gemmatalis nucleopolyhedrovirus (AgMNPV) is being widely used on a large scale in Brazil to control the velvetbean caterpillar Anticarsia gemmatalis Hubner (Lepidoptera: Noctuidae), which is a serious pest of soybeans (Moscardi and CorreaFerreira, 1985; Moscardi, 1989). Despite the intense use of AgMNPV, little is known about the infection process in vitro and the molecular biology of the virus (Castro et al., 1997).

This work describes the characterization of the structural and ultrastructural changes and the patterns of protein synthesis during the infection of A. gemmatalis cells (UFL-AG-286) (Sieburth and Maruniak, 1988a) with the baculovirus AgMNPV and the involvement of the cytoskeleton in this process.

\section{MATERIALS AND METHODS}

\section{Cell Culture and Virus}

A. gemmatalis cells were grown at $26^{\circ} \mathrm{C}$ in TC 100 medium (Gardiner and Stockdale, 1970) containing $10 \%$ fetal bovine serum. Supernatants of UFL-AG-286 cells infected with budded virus of the AgMNPV isolate 2D (AgMNPV-2D) (Sieburth and Maruniak, 1988b) were used as the virus inoculum. The amount of virus in the inoculum was measured by the TCID50 method, following the protocol described in O'Reilly et al. (1992).

\section{Light Microscopy}

UFL-AG-286 cells (1 3 106) were seeded onto several 60-mm petri dishes and left for 1 $\mathrm{h}$ at room temperature in order to allow the attachment of the cells to the bottom of the dish. 
The medium was removed and AgMNPV-2D was added to the cells at a multiplicity of infection (MOI) of approximately $10 \mathrm{pfu} / \mathrm{cell}$ (mockinfected cells were inoculated with fresh medium). The dishes were then incubated for $1 \mathrm{~h}$ at room temperature and the virus inoculum was replaced with fresh medium (zero time postinfection, p.i.). At several times p.i. $(12,24,48$, and $64 \mathrm{~h}$ p.i.), a sample of the cells was analyzed and photographed with a Zeiss Axiophot light microscope using Nomarski differential interference optics.

\section{Scanning Electron Microscopy}

UFL-AG-286-infected cells at different times postinfection (as described above) were washed in phosphate buffered saline (PBS), attached to poly-L-lysine-coated glass coverslips, and immersed in fixative ( $2 \%$ glutaraldehyde, $2 \%$ paraformaldehyde buffered in $0.1 \mathrm{M}$ sodium cacodylate, pH 7.3). Fixation was carried out at room temperature for $1 \mathrm{~h}$. Primary fixation was followed by rinsing in the same buffer and postfixation for $30 \mathrm{~min}$ in $1 \%$ osmium tetroxide. After fixation, the cells were dehydrated through an ascending acetone series, critical-pointdried in CO2, covered with a layer of gold, and observed with a JEOL JSM 840 scanning electron microscope at an accelerating voltage of $10.0 \mathrm{kV}$.

\section{Fluorescence Microscopy}

For observation of filamentous actin, UFL-AG-286- infected cells at different times p.i. (as described above) were washed in PBS, attached to poly-L-lysine-coated glass coverslips, fixed for $20 \mathrm{~min}$ in $4 \%$ paraformaldehyde, and then transferred to $4 \%$ paraformaldehyde and $0.1 \%$ Triton $\mathrm{X}-100$ for $10 \mathrm{~min}$. Fixed cells were rinsed in PBS for $15 \mathrm{~min}$ and incubated for $1 \mathrm{~h}$ in rhodamine-conjugated phalloidin. Cells were then rinsed in PBS and mounted in $90 \%$ glycerol in PBS. For localization of microtubules, UFL-AG-286-infected cells at different times postinfection were washed in PBS, attached to poly-L-lysine-coated glass coverslips, fixed in methanol for $10 \mathrm{~min}$, and transferred to acetone for $5 \mathrm{~min}$. Fixed cells were rinsed in PBS for 15 min and preincubated for 30 min in PBS containing 1\% bovine serum albumin (BSA) to block nonspecific binding. Samples were then incubated for $45 \mathrm{~min}$ at room temperature with a mouse monoclonal antibody against a-tubulin at a dilution of 1:400). After a thorough rinse with PBS, the samples were incubated for $1 \mathrm{~h}$ with the secondary antibody (goat anti-mouse fluorescein-conjugated IgG at a dilution of 1:400). Cells were then rinsed in PBS and mounted in $90 \%$ glycerol in PBS. The samples were then viewed and photographed using a Zeiss Axiophot photomicroscope equipped for fluorescence microscopy. 


\section{Pulse Chase Analysis}

Protein synthesis in UFL-AG-286 cells infected with AgMNPV-2D at various times p.i. was examined according to the protocol described by Lerch and Friesen (1992). Monolayers of UFL-AG-286 cells (1 3106 cells/ 60-mm plate) were either mock-infected with TC 100 medium or infected with AgMNPV-2D at a MOI of 10. After a 1-h adsorption period at room temperature (zero $\mathrm{h}$ p.i.), the virus inoculum was removed and replaced with TC 100 . At different times p.i. the medium was removed and replaced with PBS ( $\mathrm{pH}$ 6.2), followed by a 30 min incubation at $26^{\circ} \mathrm{C}$ to allow cells to consume surplus amino acids contained in the medium. The PBS was then removed and replaced by PBS containing $25 \mu \mathrm{Ci} /$ plate 35S-labeled methionine (Amersham). After a 1 -h incubation at $26^{\circ} \mathrm{C}$ the cells were resuspended and collected by centrifugation. The cell pellet was then resuspended in PBS and frozen at $280^{\circ} \mathrm{C}$ prior to SDS-PAGE. An aliquot of cells was subjected to lysis by mixing them with the electrophoresis sample buffer containing SDS. Electrophoresis was then carried out as previously described (Laemmli, 1970). After electrophoresis the gel was stained, soaked in the fluorographic reagent Amplify (Amersham) for 30 minutes, dried, and exposed to a Kodak XOMAT X-ray film. The autoradiograph was then analyzed for the presence of radiolabeled proteins.

\section{RESULTS}

\section{Structural Changes during Infection Visualized by Light}

Microscopy UFL-AG-286 cells were mock-infected or infected with AgMNPV at a MOI of 10. At various times p.i. the cells were observed with a light microscope. Mock infected cells showed different morphological cell types, with round and mainly elongated cells showing several cell membrane projections (Fig. 1A). At $12 \mathrm{~h}$ p.i., the cells became more rounded and there was a reduction in the size and number of cell membrane projections (Fig. 1B). By $24 \mathrm{~h}$ p.i., the great majority of cells were round in shape and hypertrophy of the cell nucleus was very pronounced. We also observed the presence of dense granular material in the cell nucleus (Fig. 1C). By $48 \mathrm{~h}$ p.i., cell nucleus showed several occlusion bodies around the granular material (Fig. 1D), and by $64 \mathrm{~h}$ p.i., the cell nucleus was full with occlusion bodies and the cytoplasm was considerably reduced in size (Fig. 1E). 


\section{Scanning Electron Microscopy}

In order to study the cytopathic effects of virus infection on the three-dimensional changes in cellular surface morphology in more detail we used scanning electron microscopy. UFL-AG-286 cells were mockinfected and infected with AgMNPV at a MOI of 10. At various times p.i., the cells were observed with a Jeol 840 JSM scanning electron microscope. Mockinfected cells showed, as described above, several cell morphological types and several long cell membrane projections (Fig. 2A). At $12 \mathrm{~h}$ p.i., the cells were more rounded and there was a dramatic reduction in the number and size of the cell membrane projections (Fig. 2B). At $24 \mathrm{~h}$ p.i., most cells were completely rounded and lacked membrane projections (Fig. 2C). At $48 \mathrm{~h}$ p.i., it was possible to observe the outline of intranuclear virus occlusion bodies through the cell membrane (Fig. 2D). At $64 \mathrm{~h} \mathrm{p.i.,} \mathrm{the} \mathrm{cells} \mathrm{became} \mathrm{very} \mathrm{fragile} \mathrm{and} \mathrm{it} \mathrm{was} \mathrm{common} \mathrm{to} \mathrm{see}$ fragmented cells showing clusters of occlusion bodies (Fig. 2E).

\section{Alterations of Actin Filaments and Microtubules during Infection}

In order to detect changes in the distribution of cytoskeletal components during the infection of UFLAG-286 cells by AgMNPV, we used immunofluorescence with a specific antibody against a-tubulin and rhodamine-conjugated phalloidin for the detection of microtu bules and actin filaments, respectively. Mock-infected cells showed the presence of actin filaments in the cell membrane projections (Fig. 3A) and microtubules forming a network of filaments in the cytoplasm (Fig. 3B). At $24 \mathrm{~h}$ p.i., actin filaments were present underneath the cell membrane, around and probably inside the cell nucleus (Fig. $3 \mathrm{C}$ ). At this time, microtubules were redistributed forming a diffuse mass in the cytoplasm (Fig. 3D). At $48 \mathrm{~h}$ p.i., the actin and microtubules filaments had the same pattern of organization found at $24 \mathrm{~h} \mathrm{p.i.}$ (not shown).

\section{Changes in Protein Synthesis during Infection}

Characteristic changes occur in the patterns of protein expression during infection of IPLB-SF-21 cells with AcMNPV. As infection progresses, production of cellular proteins is considerably reduced, while viral proteins begin to appear in increasing amounts. These changes culminate with the shutoff of cellular proteins synthesis (Carstens et al., 1979; Dobos and Cochan, 1980; Kelly and Lescott, 1981; Maruniak and Summers, 1981; Pennock et al., 1984; Rohel and Faulkner, 1984; Wilson and Miller, 1986). During AgMNPV infection of UFL- 
AG-286 cells, we noted a similar decrease in the number of proteins being synthesized at different times p.i. This transition was more noticeable between 48 and $72 \mathrm{~h}$ (Fig. 4, compare lanes 48 and 72). Viralinduced proteins were visible as early as $6 \mathrm{~h}$ p.i. (Fig. 4, compare lanes $\mathrm{M}$ and 6) and polyhedrin, which is produced in large amounts during the very late phase of infection, was first detected at $48 \mathrm{~h} \mathrm{p.i.} \mathrm{on} \mathrm{the} \mathrm{autoradiograph} \mathrm{as} \mathrm{an} \mathrm{intense} \mathrm{and} \mathrm{thick} \mathrm{band}$ (Fig. 4, lane 48). At $72 \mathrm{~h}$ p.i., almost all protein synthesized by the cell was polyhedrin (Fig. 4, lane 72). Several other bands which were initially absent on the mock-infected lane were detectable at $48 \mathrm{~h}$ p.i. (Fig. 4, compare lanes $\mathrm{M}$ and 48 ). At $96 \mathrm{~h} \mathrm{p.i.,} \mathrm{only} \mathrm{the} \mathrm{polyhedrin}$ protein was visible on the autoradiogram (Fig. 4, lane 96).

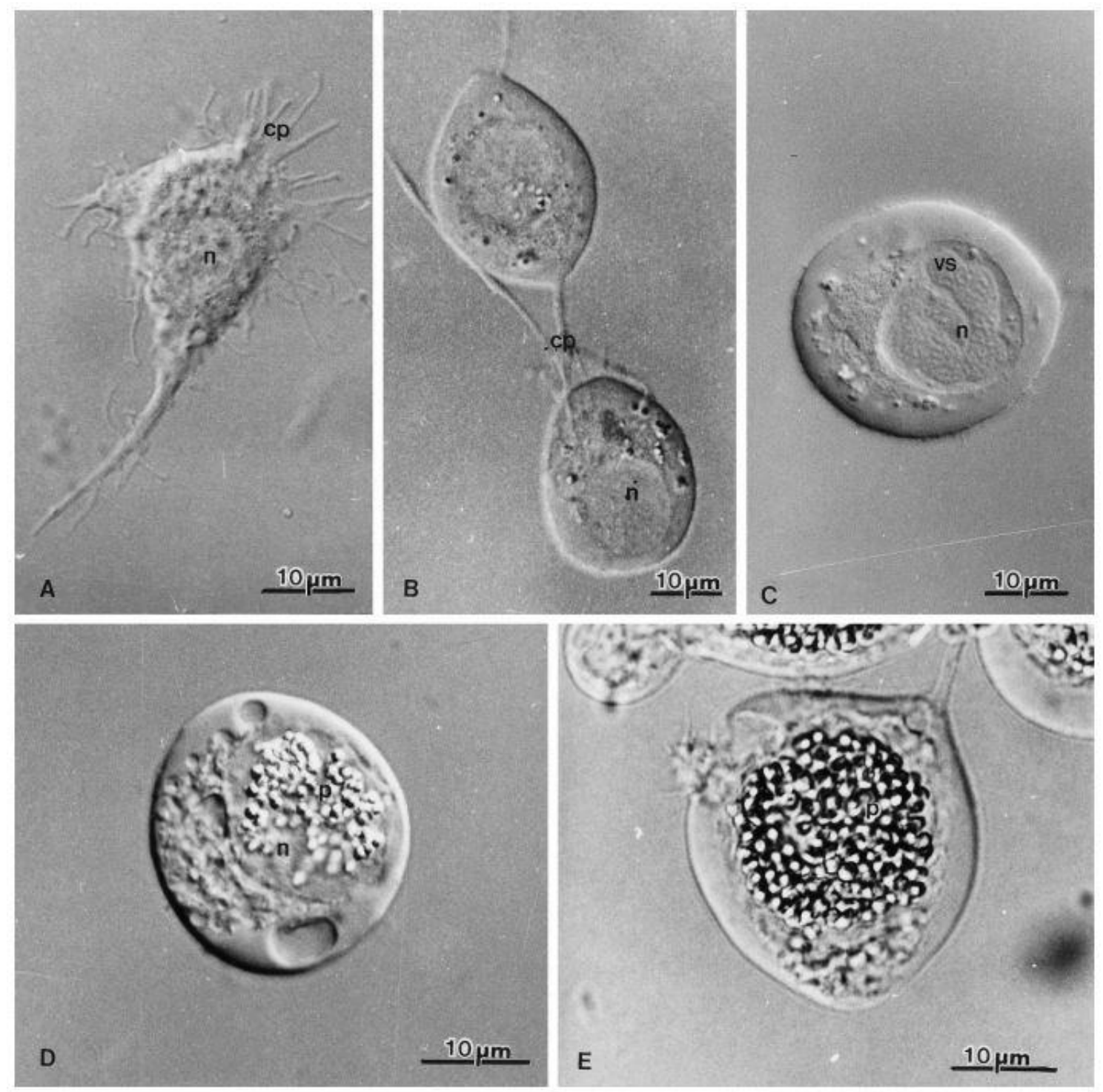

FIG. 1. Light micrographs of UFL-AG-286 cells infected with AgMNPV-2D at different times post-infection (p.i.). (A) Mock-infected cell; (B-E) infected cells at 12, 24, 48, and $64 \mathrm{~h}$ p.i., respectively. $\mathrm{cp}$, cell projections; $n$, cell nucleus; $p$, polyhedra; vs, virogenic stroma. 

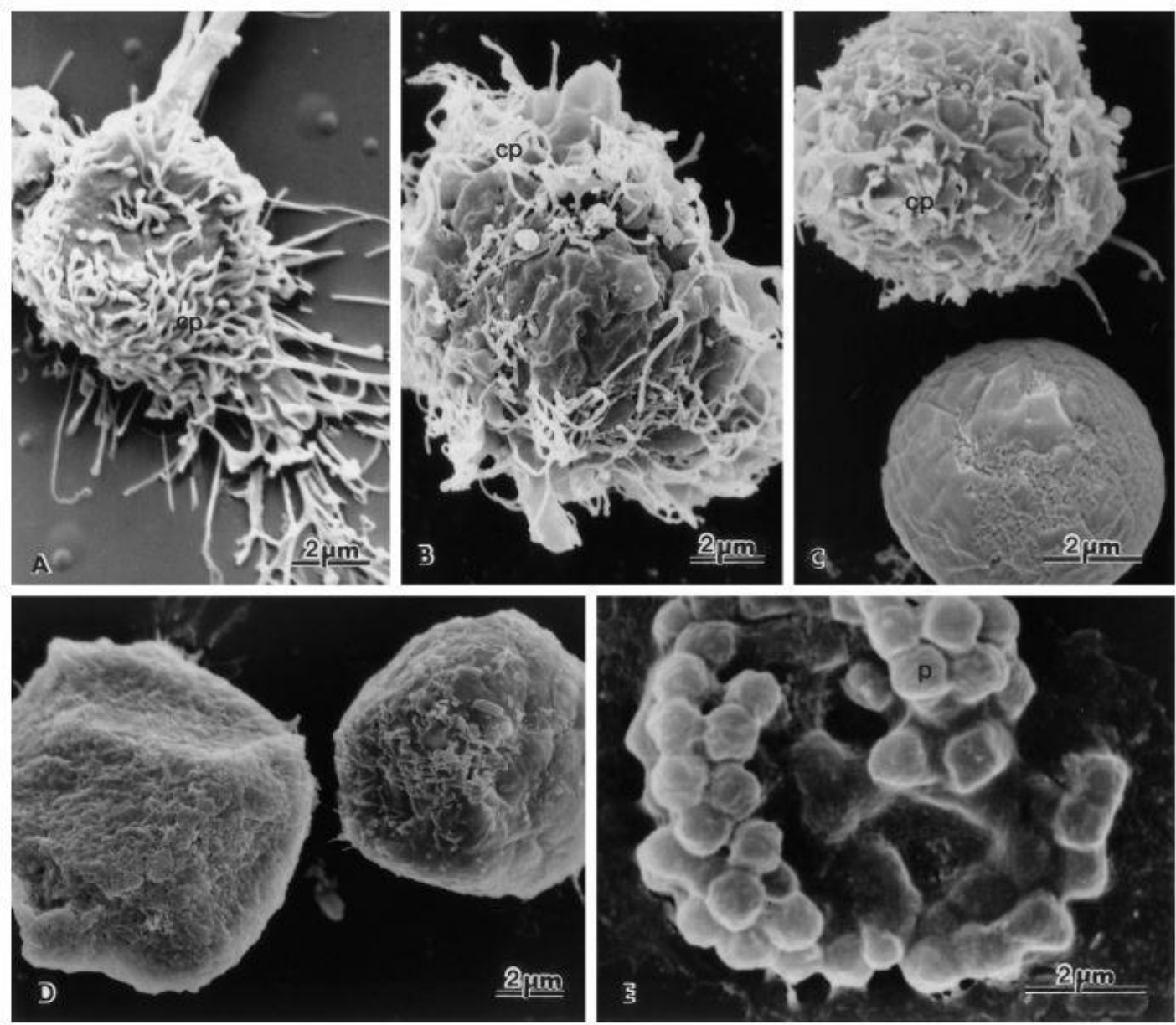

FIG. 2. Scanning electron micrographs of UFL-AG-286 cells infected with AgMNPV-2D. (A) Mock-infected; (B-E) infected cells at $12,24,48$, and $64 \mathrm{~h}$ p.i., respectively. $\mathrm{cp}$, cell projections; $\mathrm{p}$, polyhedra.
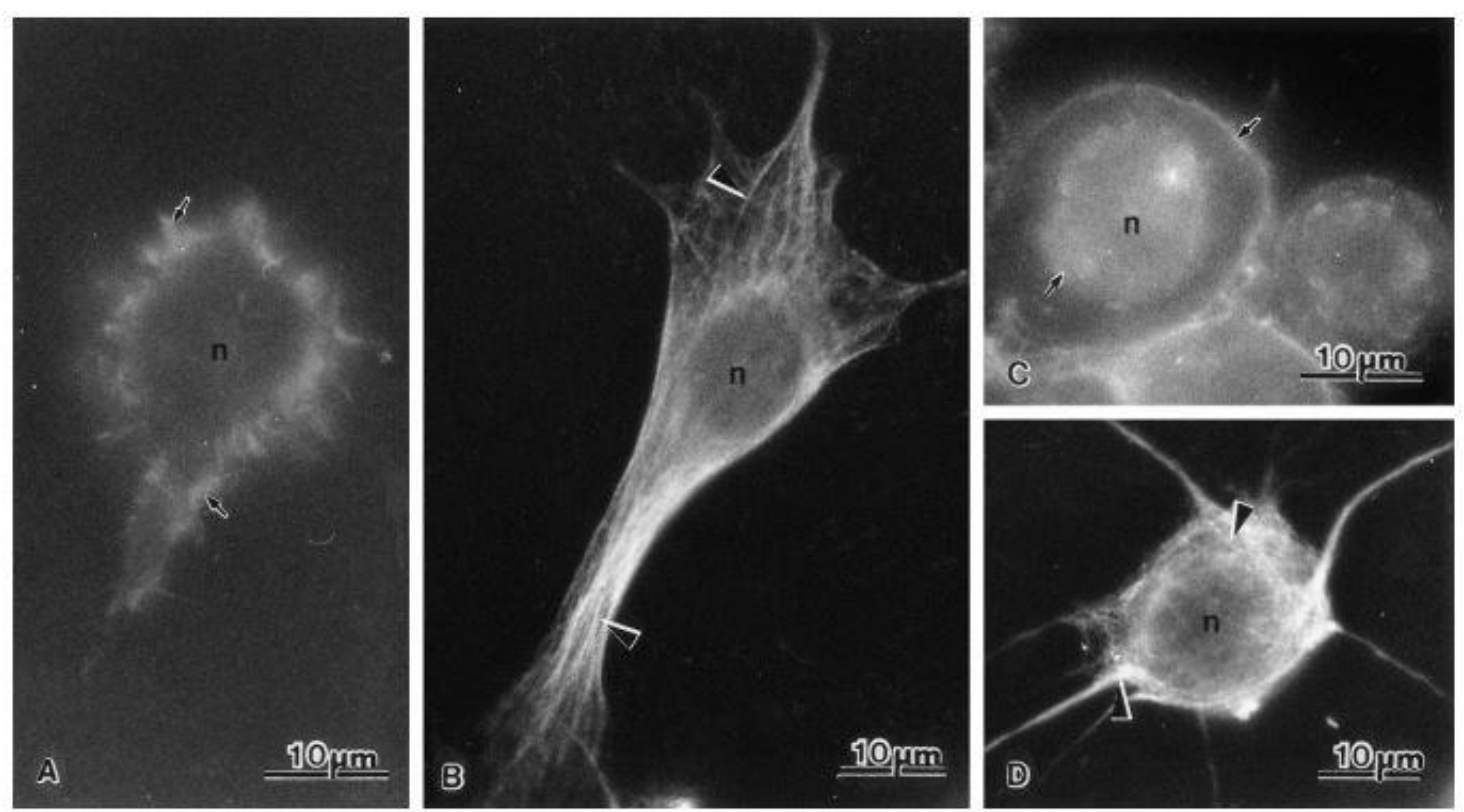

FIG. 3. Fluorescence micrographs of UFL-AG-286 cells infected with AgMNPV-2D. (A and C) Mockinfected and $24 \mathrm{~h}$ p.i. cells, respectively, showing the distribution of actin filaments using rhodamineconjugated phalloidin. ( $B$ and D) Mock-infected and $24 \mathrm{~h}$ p.i. cells, respectively, showing the distribution of microtubules using a monoclonal antibody to a-tubulin and an anti-mouse fluorescein-conjugated IgG antibody. $n$, nucleus; actin filaments (arrows); microtubules (arrowheads). 


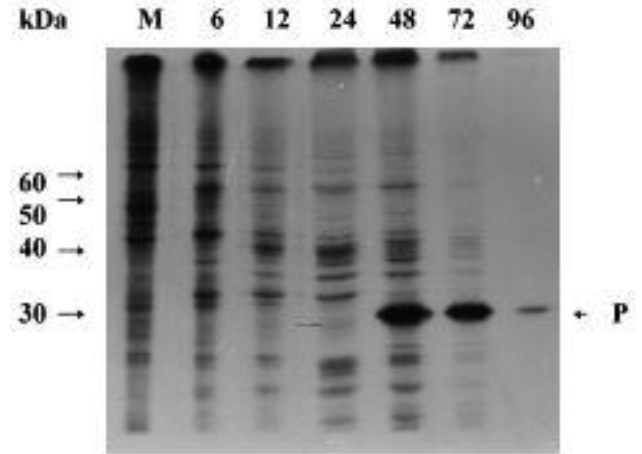

FIG. 4. Autoradiogram of a $14 \%$ SDS-PAGE containing radiolabeled proteins synthesized during infection of UFL-AG-286 cells with AgMNPV-2D. M, mock-infected, and 6, 12, 24, 48, 72, 96 represent the proteins synthesized at the respective time p.i. The numbers and arrows on the left represent the size and positions of protein molecular weight markers. P, polyhedrin.

\section{DISCUSSION}

In this work we have described the structural and ultrastructural changes of UFL-AG286 cells during infection by the baculovirus AgMNPV. Furthermore, we have shown that the cell cytoskeleton is reorganized during infection and that the pattern of protein synthesis changes during infection with the occlusion body protein (polyhedrin) being expressed late in infection.

Witt and collaborators (1977) showed the utility of scanning electron microscopy for the study of the three-dimensional changes at the cell surface of an insect tissue culture cell line (TN-386 cells) infected with AcMNPV. We have shown that mock-infected UFL-AG-286 cells have a variety of morphological types but that most prominent and distinguished feature of these cells was the presence of numerous cell membrane projections. This feature was more evident when the cells were examined by scanning electron microscopy. During the first $12 \mathrm{~h}$ following virus infection we observed changes to the cell morphology typical of baculovirus infection, such as cell rounding and hypertrophy of the nucleus (Volkman and Keddie, 1990). Furthermore, we have seen a decrease in the size and amount of cell membrane projections. These morphological changes can be attributed in part to changes of the cell cytoskeleton due to the infection process. It has been shown that cytoskeleton components undergo alteration during virus infection of different animal cells (Avalos et al., 1997). Volkman and colleagues (Volkman et al., 1987; Volkman, 1988; Hess et al., 1989) showed that cytochalasins $B$ and $D$ prevent the production of the infectious budded form of AcMNPV during the infection process in IPLB-SF-21 cells and therefore proposed that actin filaments play a role in nucleocapsid assembly. We found that the actin filaments of mockinfected UFL-AG-286 cells were present on the cell membrane projections and that after infection by AgMNPV the actin filaments were reorganized around and probably inside the cell 
nucleus. Our results are in agreement with studies carried out in vitro by Charlton and Volkman (1991) who showed that the baculovirus AcMNPV alters cellular filamentous actin in a sequential manner. During infection of IPLB-SF-21 cells by AcMNPV, actin filaments are reorganized in a manner that they break down around the cell membrane and reform within the nucleus where they may play a role in nucleocapsid morphogenesis, since they colocalize with the major capsid protein, p39. Recent work by Lanier and collaborators (1996) has identified two distinct budded virus associated actin-targeting activities. The first was a nucleocapsid actin-binding activity that may induce actin polymerization and cable formation. The second was a protease that specifically degraded actin and was identified as V-CATH, a cathepsinlike protease that is a product of the AcMNPV v-cath gene.

Besides microfilaments, microtubules are also dramatically altered during the infection process of IPLBSF-21 cells by AcMNPV (Volkman and Keddie, 1990). When insect cells are treated with the microtubule destabilizing drug colchicine the cells round up in a way similar to that occurring during infection by AcMNPV (Volkman and Keddie, 1990). Volkman and Zaal (1990) showed that efficient virus infection and replication were not dependent upon intact microtubules and they postulated that the depolymerization of microtubules late in infection may be associated with a mechanism whereby host cells are induced to exit from G0-G1 and enter S-phase, which is a necessary state for the efficient replication of most DNA virus genomes. We found that microtubules were reorganized during infection of UFL-AG-286 cells by AgMNPV. Mock-infected cells showed a vast network array of microtubules in the cell cytoplasm and late in infection these microtubules were probably depolymerized forming a diffuse staining pattern.

We have shown that host protein synthesis during the infection of UFL-AG-286 cells by AgMNPV is reduced late in infection. The shutoff of host protein synthesis is a common event that occurs during infection of insect cells by baculoviruses. Ooi and Miller (1988) showed that during infection of IPLB-SF-21 cells by AcMNPV, the levels of transcripts of some host genes (actin, histone, and hsp70) were substantially reduced from 12 to $18 \mathrm{~h}$ p.i. Other researchers have shown that at late times p.i., the incorporation of radiolabeled amino acids into hostspecific proteins (Kelly and Lescott, 1981; Maruniak and Summers, 1981) is substantially reduced. The mechanisms for such reduction in host transcription and protein synthesis are still unknown; however viral proteins are very likely to account for these changes.

In summary, the events that happen during infection of UFL-AG-286 cells concerning the cytopathic effects, reorganization of cytoskeleton components, and shutoff of host protein synthesis were very similar to those that occur in the infection process of IPLB-SF-21 cells by AcMNPV. 


\section{ACKNOWLEDGMENTS}

We thank Dr. Lois K. Miller and Dr. David O'Reilly for their helpful and critical review of the manuscript. This work was supported by Fundação de Amparo a Pesquisa do Distrito Federal (FAPDF), Conselho Nacional de Desenvolvimento Científico e Tecnológico (CNPq), and Programa de Apoio aos Núcleos de Excelência (PRONEX).

\section{REFERENCES}

Avalos, R. T., Yu, Z., and Nayak, D. P. 1997. Association of influenza virus NP and M1 proteins with cellular cytoskeletal elements in influenza virus-infected cells. J. Virol. 71, 2947-2958.

Carstens, E. B., Tija, S. T., and Doerfler, W. 1979. Infection of Spodoptera frugiperda cells with Autographa californica nuclear polyhedrosis virus. I. Synthesis of intracellular proteins after virus infection. Virology 99, 7991-7995.

Castro, M. E. B., Souza, M. L., Araujo, S., and Bilimoria, S. 1997. Replication of Anticarsia gemmatalis nuclear polyhedrosis virus in four lepidopteran cell lines. J. Invertebr. Pathol. 69, 40-45.

Charlton, C. A., and Volkman, L. E. 1991. Sequential rearrangement and nuclear polymerization of actin in baculovirus-infected Spodoptera frugiperda cells. J. Virol. 65, 1219-1227.

Charlton, C. A., and Volkman, L. E. 1993. Penetration of Autographa californica nuclear polyhedrosis virus nucleocapsids into IPLB Sf 21 cells induces actin cable formation. Virology 197, 245-254.

Dobos, P., and Cochran, M. A. 1980. Protein synthesis in cells infected by Autographa californica nuclear polyhedrosis virus (AcNPV). The effect of cytosine arabinoside. Virology 103, 446-464.

Gardiner, G. R., and Stockdale, H. 1970. Two tissue culture media for production of lepidopteran cells and nuclear polyhedrosis viruses. J. Invertebr. Pathol. 25, 363-370.

Hess, R. T., Goldsmith, P. A., and Volkman, L. E. 1989. Effect of cytochalasin D on cell morphology and ACMNPV replication in a Spodoptera frugiperda cell line. J. Invertebr. Pathol. 53, 169-182.

Kelly, D. C., and Lescott, T. 1981. Baculovirus replication: Protein synthesis in Spodoptera frugiperda cells infected with Trichoplusia ni nuclear polyhedrosis virus. Microbiologica 4, 3557.

Laemmli, U. K. 1970. Cleavage of structural proteins during the assembly of the head of bacteriophage T4. Nature 227, 680-683.

Lanier, L. M., Slack, J. M., and Volkman, L. E. 1996. Actin binding and proteolysis by the baculovirus AcMNPV: The role of virionassociated V-CATH. Virology 216, 380-388. 
Lerch, R. A., and Friesen, P. 1992. The baculovirus-integrated retrotransposon TED encodes gap and pol proteins that assemble into viruslike particles with reverse transcriptase. J. Virol. 66, 1590-1601.

Maruniak, J. E. 1986. Baculovirus structural proteins and protein synthesis. In "The Biology of Baculoviruses" (R. R. Granados and B. A. Federici, Eds.), pp. 129-146. CRC Press, Boca Raton, FL.

Maruniak, J. E., and Summers, M. D. 1981. Autographa californica nuclear polyhedrosis virus phosphoproteins and the synthesis of intracellular proteins after virus infection. Virology 109, 25-34.

Moscardi, F. 1989. Use of viruses for pest control in Brazil: The case of the nuclear polyhedrosis virus of the soybean caterpillar, Anticarsia gemmatalis. Mem. Inst. Oswaldo Cruz 84, 51-56.

Moscardi, F., and Correa-Ferreira, B. S. 1985. Biological control of soybean caterpillars. In "World Soybean Research Conference III: Proceedings" (R. Shibles, Ed.), pp. 703-711. Westview Press, Boulder, London.

Murphy, F. A., Fauquet, C. M., Bishop, D. H. L., Ghabrial, A. W., Jarvis, A. W., Martelly, G. P., Mayo, M. E., and Summers, M. D. 1995. "Virus Taxonomy: Classification and Nomenclature of Viruses, Sixth Report of the International Committee on Taxonomy of Viruses." SpringerVerlag, Wien, New York.

Ooi, B. G., and Miller, L. K. 1988. Regulation of host RNA levels during baculovirus infection. Virology 166, 515-523.

O’Reilly, D. R., Miller, L. K., and Luckow, V. A. 1992. "Baculovirus Expression Vectors. A Laboratory Manual.” Freeman, San Francisco, CA.

Pennock, G. D., Shoemaker, C., and Miller, L. K. 1984. Strong and regulated expression of E. coli beta-galactosidase in insect cells using a baculovirus vector. Mol. Cell. Biol. 4, 399-406.

Rohel, D. Z., and Faulkner, P. 1984. Time course analysis and mapping of Autographa californica nuclear polyhedrosis virus transcripts. J. Virol. 50, 739-747.

Sieburth, P. J., and Maruniak, J. E. 1988a. Growth characteristics of a continuous cell line from the velvetbean caterpillar, Anticarsia gemmatalis Hubner (Lepidoptera: Noctuidae). In Vitro. Cell. Dev. Biol. 24, 195-198.

Sieburth, P. J., and Maruniak, J. E. 1988b. Susceptibility of an established cell line of Anticarsia gemmatalis (Lepidoptera: Noctuidae) to three nuclear polyhedrosis viruses. J. Invertebr. Pathol. 52, 453-458.

Vaugh, J. L., Goodwin, R. H., Tompkins, G. L., and McCawley, P. 1977. The establishment of two cell lines from the insect Spodoptera frugiperda (Lepidoptera: Noctuidae). In Vitro 13, 213217.

Volkman, L. E. 1988. Autographa californica MNPV nucleocapsid assembly: Inhibition by cytochalasin D. Virology 163, 547-553. 
Volkman, L. E., Goldsmith, P. A., and Hess, R. T. 1987. Evidence for microfilament involvement in budded Autographa californica nuclear polyhedrosis virus production. Virology 148, 288297.

Volkman, L. E., and Keddie, B. A. 1990. Nuclear polyhedrosis virus pathogenesis. Sem. Virol. 1, 249-256.

Volkman, L. E., Storm, K., Aivazachvili, V., and Oppenheimer, D. 1996. Overexpression of actin in AcMNPV-infected cells interferes with polyhedrin synthesis and polyhedra formation. Virology 225, 369-376.

Volkman, L. E., and Zaal, K. J. M. 1989. Autographa californica M nuclear polyhedrosis virus: Microtubules and replication. Virology 175, 292-302.

Wilson, M. E., and Miller, L. K. 1986. Changes in the nucleoprotein complexes of a baculovirus DNA during infection. Virology 151, 315-328.

Witt, D. J., Janus, C. A., and Milligan, S. E. 1977. Scanning electron microscopy of cultured Trichoplusia ni cells infected with Autographa californica nuclear polyhedrosis virus. J. Invertebr. Pathol. 30, 429-433. 